\title{
Early English meter as a way of thinking
}

\section{Eric Weiskott*}

\begin{abstract}
The second half of the fourteenth century saw a large uptick in the production of literature in English. This essay frames metrical variety and literary experimentation in the late fourteenth century as an opportunity for intellectual history. Beginning from the assumption that verse form is never incidental to the thinking it performs, the essay seeks to test Simon Jarvis's concept of "prosody as cognition", formulated with reference to Pope and Wordsworth, against a different literary archive.

The essay is organized into three case studies introducing three kinds of metrical practice: the half-line structure in Middle English alliterative meter, the interplay between Latin and English in Piers Plowman, and final - $e$ in Chaucer's pentameter. The protagonists of the three case studies are the three biggest names in Middle English literature: the Gawain poet, William Langland, and Geoffrey Chaucer.
\end{abstract}

Keywords: alliterative meter; Chaucer; historical poetics; intellectual history; medieval literary theory; meter; pentameter; Piers Plowman; Sir Gawain and the Green Knight; tetrameter

This essay is about structures of thought that happen to take the form of poetry. Thus stated, the object of inquiry would seem to be intellectual history, to which poetics is subordinated. However, the discussion to follow begins from the assumption that verse form is never incidental to the thinking it performs. Apprehending meter as a way of thinking necessarily involves reimagining thinking itself. By 'thinking' I do not only mean the paraphrasable ideas objectified in intellectual history and philosophy. Rather, I propose to demonstrate conformity between ideas and meter in early English verse. At the level of metrical structuration, where language becomes verse, meter and thinking are one and the same.

The title of this essay echoes Simon Jarvis (1998), who recommends approaching "prosody as cognition". Jarvis had Alexander Pope and William Wordsworth in mind when he coined that phrase. I seek to test Jarvis's concept against a different literary archive, exploring the particular kinds of thinking

* Author's address: Eric Weiskott, Stokes Hall S407, Boston College, Chestnut Hill, Mass. 02467; email: eric.weiskott@bc.edu. 
done by and through early English meter. The essay focuses on the second half of the fourteenth century, a stretch of decades that saw a large uptick in the production of literature in English. In medieval England, as I will argue, meter was a way of thinking about form and balance, translation and vernacularity, and the historicity of literary practice. The essay is organized into three case studies introducing three kinds of metrical practice: the half-line structure in Middle English alliterative meter, the interplay between Latin and English in Piers Plowman, and final $-e$ in Chaucer's pentameter.

The protagonists of the three case studies are the three biggest names in Middle English literature: the Gawain poet, William Langland, and Geoffrey Chaucer (d. 1400). The first of these is no name at all but a cypher: the Gawain poet (or Pearl poet), a Northwest Midland writer thought to have composed the four Middle English poems in British Library Cotton Nero MS A.x (copied c. 1390). For this poet, no compelling external evidence for authorship has been identified (Andrew 1997; Duggan 1997). William Langland is little more than a floating name in literary history. Mentioned in a few contemporary documents and identified as the author of a poem called Piers Plowman in an early fifteenth-century manuscript note (in Dublin, Trinity College, MS 212), Langland probably belonged to the well-to-do Rokele family and likely spent time in London (Kane 1965; Hanna 1993; Adams 2013; Johnston 2016). The name 'Langland' itself may be a pseudonym. Chaucer, of course, is the Grand Poobah of medieval English literature. Like Gilbert and Sullivan's character, Chaucer was chronically overemployed; a resident of London, at one time or another he worked as a clerk, comptroller of customs, diplomat, esquire, forester, page, and soldier, among other jobs (Carlson 2004). These three poets have garnered the lion's share of scholarly attention, and the present study follows suit by placing them at the center of an essay in historical poetics (for recent revivals of the term see Prins 2008; Jarvis 2014). But I will continually note how the metrical practice of a range of contemporary and earlier poets shaped the structures of thought informing Sir Gawain and the Green Knight, Piers Plowman, and the Canterbury Tales.

The broadest goal of this essay is to demonstrate that intellectual history and poetics can illuminate one another. Indeed, where poetry is concerned, the procedures of the two fields ought to coincide. Medievalists have made significant contributions toward understanding poetry as cognition, especially in the work of Andrew Galloway (Grady, Galloway 2013; Galloway 2016), Eleanor Johnson, Alastair Minnis (Minnis, Scott 1992; Minnis 2011), Fiona Somerset and Nicholas Watson, and Jocelyn Wogan-Browne (Wogan-Browne et al. 1999 and 2016) under the banner of what Minnis calls 'medieval literary theory'. This research program compares the explicit theories of authority and 
textuality propounded in Latin by medieval scholars with the often implicit theorization of literature performed by vernacular texts themselves. To date, few medievalists have considered the intellectual significance of English meter as such, though Thomas Cable (1991: 134) has laid the groundwork for this project by insisting that the study of meter is fundamentally about "mental structures" rather than objective linguistic or acoustic data. Following Cable, I do not claim that meter stands in a one-to-one relationship to a given public taste or religious conviction, but that meter itself constitutes a way of thinking, a form of cognition, and as such pertains to intellectual history no less than to poetics.

From the perspective of intellectual history, this essay seeks to enrich the study of medieval literary theory by disaggregating the medieval English literary field by metrical tradition. Alliterative meter does not think the same way pentameter thinks; the difference should matter in any account of medieval literary theory. From the perspective of poetics, this essay seeks to redirect the philological procedures of the highly traditionalist field of metrics toward a phenomenological poetics. The intellectual implications of metrical practice have long remained hidden behind a lingustic formalism that posits meters as direct expressions of languages. A phenomenological poetics, building on but also moving beyond linguistic description of verse form, approaches meter as a historically mediated event that occurs in the minds of poets, scribes, and readers (Weiskott 2016:2-3). If meter lives in the mind, then it is part of the job of a metrist to discover what it is doing up there.

\section{Asymmetry}

In the early eighth century, English poetry first found its way onto the manuscript page. When it did, it appeared in an early form of alliterative meter, now known as Old English meter. In the middle of the sixteenth century, alliterative poetry disappeared from the active repertoire of verse forms. By then, Chaucer's pentameter had become the default English meter. These are the outer chronological limits of English alliterative verse. In the 800 years in between, the alliterative tradition functioned as a gigantic and slow-moving cultural institution (Weiskott 2016). The alliterative tradition was gigantic: over 300 poems survive, many of them thousands of lines long. The alliterative tradition was slow-moving: the major changes in the metrical system took centuries to crystallize. And the alliterative tradition was an institution: for 800 
years it stood as a set of cultural practices from which poets drew or against which they staked their literary projects.

The account of metrical history offered in the previous paragraph conflicts with a prominent twentieth-century literary-historical concept, the so-called 'Alliterative Revival', whereby alliterative verse was resuscitated in the 1350s like an Anglo-Saxon zombie (Turville-Petre 1977; for historiography see Cornelius 2012). Seeking an intellectual context for the 'Revival', modern scholars have wanted Middle English alliterative verse to enact metaliterary gestures toward its own metrical form. Many scholars think they have caught the Gawain poet doing this near the beginning of Sir Gawain and the Green Knight. After situating Britain in the long history of European colonization, the poet adjures the reader or listener (quoted from Andrew, Waldron 2010, with a tabbed space representing the caesura; translation mine):

If ze wyl lysten pis laye bot on littel quile,

I schal telle hit astit, as I in toun herde,

With tonge.

As hit is stad and stoken

In stori stif and stronge,

With lel letteres loken,

In londe so hatz ben longe.

("If you will listen to this lay just a little while, I will tell it as readily as I heard it spoken [lit., 'with tongue'] in town. As it is set down and fixed in a brave and sturdy chronicle, enclosed in loyal letteres, so it has long been in the land".)

Critics are probably overly optimistic in identifying a reference to meter here. The word letteres is ambiguous. It could mean 'letters' with reference to alliterating sounds; but letteres also means 'learning' and 'writing' in Middle English (Middle English Dictionary Online, 'lettre', 5 and 3). All three senses are appropriate in context. And then, letteres crops up in a second-person address that validates the poem as oral, traditional, and authoritative. If meter appears here at all, it does so as a correlate of these other concerns. The passage is certainly noteworthy for its extended metaliterary meditation on the poem as an ancient ("In londe so hatz ben longe") and authentic narrative ("stori"), oral ("lysten"; "herde"; "With tonge") and written ("letteres"), brave and strong ("stif and stronge") like the chivalric heroes within it. But the status of the passage as a 
touchstone in discussions of Middle English alliterative meter reflects modern concerns more than medieval ones. ${ }^{1}$

The difficulty of identifying self-conscious reference to meter in this passage should not be surprising. For one thing, if recent metrical studies are correct, no such event as 'the Alliterative Revival' occurred. Students of alliterative meter increasingly characterize fourteenth-century alliterative meter as one phase in a centuries-long catena of metrical practice spanning the Old English and Middle English periods (Russom 2004; Yakovlev 2008; Cable 2009b; Weiskott 2013 and 2016; Cornelius 2017). If so, no special intellectual justification for composing alliterative verse was necessary in the fourteenth century. More generally, self-conscious references to meter were thin on the ground at a time when vernacular poetics had not yet become an academic subject or a sustained cultural discourse (Cornelius 2017: 23-43). When medieval writers seem to be mentioning or noticing English meter, it is almost always because they are mentioning or noticing something else. In short, early English meter was a vehicle for thought but almost never the object of thought in its own right. Hence this essay's focus on thinking by and through meter rather than thinking about meter.

There is a further complication to the optimistic reading of Gawain 30-36. Many metrists, ironically, no longer include alliteration among the organizing principles of alliterative meter (Cable 1991: 132; Hanna 1995: 50; Yakovlev 2008: 23-24). In recent metrical studies, alliteration appears as an ornament, standing in approximately the same relation to alliterative meter as rhyme to pentameter. The term 'alliterative verse', an eighteenth-century formulation for which no very satisfying alternative exists, is worse than a misnomer: it is a category mistake, designating a meter by a linguistic feature that cannot organize metrical patterning per se (Cable 2009a: 232). If the Gawain poet has designated the poem's metrical form with reference to the repetition of initial sounds, this corresponds to a misperception shared with a long tradition of modern prosodists but rejected in recent scholarship. ${ }^{2}$

According to current critical consensus, the most fundamental feature of alliterative verse is not alliteration but division of the metrical line into halflines. The two half-lines, known as the 'a-verse' and 'b-verse', are divided by a metrical-syntactical break or 'caesura'. At no point in the evolution from

1 For three other passages often taken as reflexive statements on alliterative meter but better interpreted otherwise, see Cornelius 2012: 270-271 and Pearsall 1977: 153-154.

2 Nor is 'accentual' a sufficiently precise descriptor for alliterative meter. Old English meter, the ancestor of fourteenth-century alliterative meter, combined morphological (Yakovlev 2008: 70-82) and quantitative (Stockwell and Minkova 1997) organizational principles. 
Old English to Middle English alliterative meter does the caesura cease to bear metrical significance. Consider the opening line of Codmon's Hymn (late seventh/early eighth c.), the earliest datable English poem, beside that of Sir Gawain and the Green Knight: "Nu scylun hergan | hefaenricaes uard" ("Now let us praise the keeper of the kingdom of heaven..."); "Sipen pe sege and pe assaut | watz sesed at Troye" ("After the siege and the onslaught had finished at Troy..."). From one end of the alliterative tradition to the other, metrical patterning plays out on the scale of the half-line. Syntax and sense typically reinforce the metrical boundary. In the opening line of Codmon's Hymn, the a-verse contains the verb while the b-verse contains the object. In the opening line of Gawain, the a-verse contains the subject while the b-verse contains the predicate. Medieval scribes often divided the a-verse and b-verse of alliterative poetry with a raised point (punctus elevatus), though this practice only occasionally rose to the level of thoroughgoing metrical punctuation (for an Old English example, see Rosier 1964: 6-7). Editors of Old English verse regularize the scribes' practice, marking the caesura with a space. Most editors of Middle English alliterative verse, frustratingly, elect not to mark the caesura at all. This minor editorial decision has a major interpretive effect, which is to suppress consciousness of the boundary between the two domains of the meter's formal/intellectual activity.

In the late fourteenth century, the caesura assumed particular importance as a flexion point between two mutually exclusive metrical arenas. As a result of metrical history, the Middle English alliterative b-verse housed a small set of highly conspicuous metrical patterns. Gawain $1 \mathrm{~b}$ instances the most common pattern: unstress, stress, multiple consecutive unstresses, stress, unstress (xSxxSx, where $S$ represents a stressed syllable and $x$ represents an unstressed syllable). There is one other basic pattern, with variations (Cable 1991: 85-113). As a result of the same metrical history, the Middle English alliterative a-verse housed a gigantic array of highly indeterminate metrical patterns. Indeed, Cable (1991: 86) argues that the Middle English alliterative line hinged on a principle of asymmetry: all patterns allowed in the a-verse were disallowed in the b-verse, and vice versa.

For modern scholars, metrical asymmetry is evidence for the continuity of the alliterative meter. Asymmetry gradually increased over time, from nearly $0 \%$ in the eighth century to roughly $35 \%$ in the twelfth century to nearly $100 \%$ in the fourteenth century. Fourteenth-century poets, of course, lacked access to metrical history as such. They could not have appreciated the historical forces bearing on verse composition. For them, metrical asymmetry was the most basic precondition of thought in this verse tradition. Asymmetry causes every Middle English alliterative line to assume the following form: 'not X or 
Y' | 'X or Y', where $X$ and $Y$ represent two major variations on a theme. It is in the variety of responses to the stricture of asymmetry that the richness of thought in alliterative verse most immediately springs into view. Consider a passage from the second stanza of Sir Gawain and the Green Knight, just before the metaliterary meditation on loyal letteres:

Ande quen pis Bretayn watz bigged bi pis burn rych

Bolde bredden perinne, baret pat lofden,

In mony turned tyme, tene pat wrozten.

Mo ferlyes on pis folde han fallen here oft

Pen in any oper pat I wot, syn pat ilk tyme.

("And when this Britain was founded by this noble man, bold ones flourished therein, [those] who loved battle, in many troubled time, [those] who wrought harm. More wonders have fallen here often in this land than in any other that I know of, since that very time".)

Following an influential late medieval British historiographical tradition, these lines describe the aftermath of the foundation of Britain by Brutus of Troy (Turville-Petre 2003). The poet segregates major ideas in the half-lines, one idea per half-line: Britain, Brutus; bold men, battle; time, harm; wonders, often; elsewhere, back then. In the first three lines, the caesura divides the prosaic word order of the a-verse from the habitually contorted syntax of the Middle English alliterative b-verse: 'by this man noble' for 'by this noble man', 'battle who loved' for 'who loved battle', and 'harm who wrought' for 'who wrought harm. These contortions have a metrical dimension: in each case, prose word order would yield an unmetrical accentual contour. Alternation between less and more artificial syntax within each line is one of the strangest and most telling features of the alliterative tradition in general and Gawain in particular. The poet thinks like Yoda, but typically only half the time. Each of the first three b-verses is also grammatically dispensable (respectively, a prepositional clause specifying the agent of an action and two relative clauses), further marking out the b-verse as poetic artifice. Cumulatively across the poem, metrical asymmetry enables what is precisely the Gawain poet's major intellectual achievement: the construction of a visceral ancient world of chivalric romance that pointedly comments on its own constructedness. 
The previous paragraph focused on certain habits of thought rendered possible by the substructure of the fourteenth-century alliterative line. The Gawain poet was also capable of breaking habits for effect:
$\begin{array}{lllllllllllllllllll} & x & S & x & x & S & x & x & S & x & x & S & x\end{array}$
pay bozen bi bonkkez per bozez ar bare;
$\begin{array}{lllllllllllllllll}x & S & x & x & S & x & & x & S & x & x & S & x\end{array}$
pay clomben bi clyffez per clengez pe colde.

("They went past banks where boughs are bare; they climbed past cliffs where the cold clings".)

(2077-2078)

These lines, from the final 'fitt' or section of the poem, describe Gawain's journey from Castle Hautdesert to the Green Chapel, accompanied by a guide. Each of the four verses shows the same metrical pattern, in direct violation of the principle of metrical asymmetry. With their metrical symmetry and syntactical parallelism, these lines stand out clearly from the poet's normal practice. Indeed, they seem imported from a different poetic tradition: Middle English alliterating, stanzaic verse as in Susannah and the Awntyrs off Arthure (Turville-Petre 1974; Kennedy 2003). A criterial difference between (unrhymed) alliterative verse and alliterating stanzaic verse is the degree to which the principle of metrical asymmetry obtains. The rhyming poems, oriented toward the line-end rather than the caesura and therefore organized at the level of the line rather than the half-line, smooth out the complexities that differentiate a-verse and b-verse in (unrhymed) alliterative meter (Weiskott 2016: 103-106; Cornelius 2017: 130-146). Rhyming, alliterating verse also differs syntactically from (unrhymed) alliterative verse (Lawton 1980). Gawain 2077-2078 thus functions as an inscribed poem-within-a-poem, a thoughtwithin-a-thought whose artificiality sets off the surrounding variegation. In these lines, metrical eclecticism is a way of rethinking a romance motif. 


\section{Macaronics}

Although the foregoing discussion emphasized the subtlety and flexibility of the Gawain poet's metrical cognition, Sir Gawain and the Green Knight rightly functions in modern scholarship as a paragon of alliterative style. Piers Plowman, by contrast, is a poem that works hard to fly under the radar of the alliterative tradition. It succeeds so well in this aim that metrists have often felt the need to isolate Piers Plowman as a special case. For example, Cable (1988: 63) confides, "I suspect that Langland knew the rules [...] but felt free to break them", while Nicolay Yakovlev (2008: 25) labels the poem "metrically deviant". More recent scholarship has sought to reopen lines of metrical communication between Piers Plowman and the rest of the alliterative tradition (Cole 2007; Barney 2009: 277-278; Cable 2009b: 247-248; Burrow 2012). In what follows, I pursue a synthesis of these critical positions by arguing that Langland stands apart from other alliterative poets not because he flouts metrical rules but because of the peculiar way in which he fulfills them.

Langland's poem is well known within and beyond the field of medieval studies, but it cuts an intimidating figure even for medievalists. Seven thousand lines long and divided into a prologue and twenty 'passūs' or steps, Piers Plowman exists in three distinct authorial versions ('A', 'B', and 'C') composed in the 1370s and 1380s. The poem stages an allegorical/apocalyptic/ philosophical inquiry into ethics and biblical history. Langland satirizes beggars, minstrels, rich folk, monks, friars, professors, but above all the secular clergy - the Pope, bishops, priests, and other ecclesiastics. Each sector of late medieval life is weighed and found wanting. Three or four times throughout the poem, a mysterious plowman named Piers emerges to galvanize the narrator Will, other people, and the reader in their metaphorical quest for truth. Piers Plowman culminates in a vision of the Passion of Jesus Christ, in which Jesus is simultaneously a persecuted god-man and a knight with a coat of arms and an entourage of biblical prophets and personified Christian virtues. It is a famously difficult poem, and it was immensely popular from the fourteenth to the sixteenth centuries.

One of the most remarkable features of Piers Plowman as a poem is its "bilingual embrace" (Steiner 2013: 6). Langland's extensive use of Latin within and around English metrical lines increases the degree of difficulty for any interpretive act, including scansion. In Piers Plowman, Latin prose citations can interrupt the English alliterative meter (quoted from Kane, Donaldson 1975, with a tabbed space representing the caesura; translation mine): 
Salomon pe sage a sermon he made

For to amenden Maires and men pat kepen [pe] lawes,

And [took hym] pis teme pat I telle pynke:

Ignis deuorabit tabernacula eorum qui libenter accipiunt munera \&c.

Among pise lettrede 1[or]des pis latyn [amountep]

That fir shal falle \& [forbrenne at pe laste]

The hou[s] and [pe] ho[m] of hem that desirep

Yiftes or yeresyeues bycause of hire Offices.

("Solomon the wise composed a sermon to amend mayors and men who keep the laws, and he took up this theme for them, which I mean to relate: Fire shall devour their tabernacles, who love to take bribes \& c. [=Job 15:34]. Among these learned lords, this Latin signifies that fire shall fall and ultimately burn up the house and home of those who desire gifts or annuities because of their positions")

Here, a longer sequence of discussion and dialogue about bribery culminates in a citation of Job. The verbatim English translation overmarks Latin as high-class and bookish ("pise lettrede lordes") and English as vulgar. While the metrical structure of the poem subordinates Latin to English, readers of Piers Plowman have often noted an uncanny effect whereby the English functions as a commentary on the as-yet-uncited Latin (Alford 1977 and 1992). In 3.93-100, for example, the translation explicitly positions the prose Latin ("pis teme"; "pis latyn") as the source of the English alliterative thoughts that surround it. This is all to say, the bilingual embrace of Piers Plowman is fully bilingual. Langland thinks in Latin and in English, and the metrical and conceptual relationships between the languages are always at issue. The complexity of the English-Latin interface in Piers Plowman can be gauged from a different angle, by appreciating the variety of strategies employed by scribes and early printers for representing Latin on the page (Alford 1992: 12-13; Jefferson 2012).

Latin can also crop up in Piers Plowman after an English alliterative a-verse:

'Bryng pacience som pitaunce pryveliche', quod Conscience;

And panne hadde Pacience a pitaunce, Pro hac orabit ad te omnis sanctus in tempore oportuno. 
(“'Bring Patience a bite to eat discreetly', said Conscience; and then Patience had a bite to eat, For this shall every one that is holy pray to thee in a seasonable time [=Psalm 31:6]”.)

In this passage, the narrator Will sits with Patience at a feast hosted by Conscience. The menu is mostly scripture, though soup, stew, and wine are also on offer. Here, Patience is served a slice of Psalm 31. I'll return to this psychedelic scene in a moment. But first, a problem of identification: what is the literary form of Latin following an alliterative a-verse? Some Latin after the a-verse in Piers Plowman is more quotation-like, as in 13.56-57, while some is more b-verse-like:

Ac shrift of moup moore worpi is if man be $y[n] l i c h e$ contrit, For schrift of moupe sleep synne be it neuer so dedly Per confessionem to a preest peccata occiduntur. ${ }^{3}$

("But confession by mouth is more effective if the person is inwardly contrite, for confession by mouth slays sin however mortal it be - by confession to a priest sins are slain".)

One might well scan, with classical accentuation, peccáta occidúntur (xSxxxSx) - an acceptable b-verse pattern, equivalent to the metrical pattern of Gawain 1b discussed above. However, the ambivalence between more quotation-like and more b-verse-like Latin means that the potential for suspension of meter exists regardless of the particular rhythmical form of the Latin. Ian Cornelius (2017) argues that Langland, unlike other alliterative poets, allowed himself the option of switching out of English alliterative meter and into Latin prose at the caesura: the ultimate Thule of metrical asymmetry.

In the passages in Piers Plowman discussed thus far, Latin stands outside the metrical structure of the poem. Langland was also capable of integrating Latin into English meter, as in the longer passage in which the "Pro hac orabit..." quotation appears:

\footnotetext{
3 For the Latin quotations in this passage in their larger literary context, see Alford 1977:
} 86-96. 
'Here is propre seruice', quod Pacience, 'ber farep no Prince bettre'.

And he brouzte vs of Beati quorum of Beatus virres makyng,

And panne a mees of ooper mete of Miserere mei deus,

Et quorum tecta sunt peccata

In a dissh of derne shrifte, Dixi \& confitebor tibi.

'Bryng pacience som pitaunce pryueliche', quod Conscience,

And panne hadde Pacience a pitaunce, Pro hac orabit ad te omnis sanctus in tempore oportuno;

And Conscience conforted vs and carped vs murye tales:

Cor contritum \& humiliatum deus non despicies.

(“'Here is proper service', said Patience; 'no prince fares better'. And he [=Scripture] brought us some of Blessed are they whose [=Psalm 31:1] of Blessed is the man's [=Psalm 31:2] making, and then a portion of other food, of Have mercy on me, God [=Psalm 50:1], and whose sins are covered [=Psalm 31:1] in a dish of private confession, I said \& I will confess [=Psalm 31:5]. 'Bring Patience a bite to eat discreetly', said Conscience; and then Patience had a bite to eat, For this shall every one that is holy pray to thee in a seasonable time [=Psalm 31:6]; and Conscience comforted us and spoke merry tales to us: A contrite and humbled heart, O God, thou wilt not despise. [=Psalm 50:19]".)

(B.13.52-58a)

At the insistence of Conscience, Scripture serves Patience and Will bits of Psalms 31 and 50. In this showstopping passage, two penitential psalms are sliced up for dinner service. Like liturgical incipits, these bits of text evoke the larger scriptural sources from which they derive. For example, 'Blessed is the man' is mentally expandable to 'Blessed is the man to whom the Lord hath not imputed sins'. Indeed, Beatus vir and Miserere are liturgical incipits, though in this capacity they refer to other psalms (to Psalm 31:2 cf. Psalm 1:1; to Psalm 50:1 cf. Psalms 4:2, 6:3, 9:14, etc.). ${ }^{4}$ While most of these scraps of psalms do not contribute to the poem's metrical shape, $13.53 \mathrm{~b}$ and $13.54 \mathrm{~b}$ witness Latin embedded in English grammar and meter. The editors' italicization in 13.53b registers an English possessive constructed from a Latin tag (cf. 10.326b). Both the second and third b-verses may be scanned with metrically normative patterns: "of Beatus virres makyng" (xSxxxxSx; metrical demotion of virres as often in alliterative b-verses); "of Miserere mei deus" (xSxxxxSx). Crucially,

4 The (as it were) incidental liturgical valence of these incipits fits with the sporadic and nonprogrammatic uses of the liturgy throughout Piers Plowman (Adams 1976). 
normative b-verse scansion is only possible by assuming anglicized accentuation rather than classical accentuation of the incipits (Béatus and Míserere not Beátus and Miserére). So phonology works together with allusions to the liturgy, grammar, meter, and the metaphorical conceit of the scene to render scripture edible. Bits of Latin psalms are ingested by Patience and Will just as they are ingested by English alliterative meter. A scansion like Béatus conveys the difference between Latin textuality in situ and Latin textuality reinscribed as dinner in an English poem. In 13.52-58a, Langland is able to imagine the process of reading Latin scripture as a process of consuming English meter.

The peculiar way in which Langland fulfills metrical rules applies not only to Latin but also to English itself. As a result of the long history of the alliterative tradition, fourteenth-century alliterative poets consistently versified with twelfth- and thirteenth-century word-forms no longer pronounced in everyday speech. This phantom phonology is a characteristic feature of alliterative meter; it helps carry the meter's historical baggage (Cable 1991: 85-113; Weiskott 2013). Langland, however, mixes linguistically conservative and contemporary word-forms:

$x \quad S \quad x x \quad x S x$
the meene and the riche

("the poor and the rich")

(B.Prol.18b)

$\begin{array}{lllll}\mathrm{x} & \mathrm{x} & \mathrm{S} & \mathrm{x} & \mathrm{S} \mathrm{x}\end{array}$

amonges riche and pouere.

(“among rich and poor”)

$(10.77 b)$

In Prol.18b, the plural adjective riche counts an etymologically justified phantom $-e$. In $10.77 b$, meter indicates that the $-e$ in riche is discounted in scansion. This alternation is analogous to alternation between classical and anglicized scansion of Latin words in Piers Plowman. Sprinkling innovative English or Latin phonology in the oldest English meter is the metrical equivalent of portraying the Crucifixion as a chivalric tournament. In both cases, Langland manages to fulfill and disappoint expectations at the same time, turning 
familiar literary gestures into something strange and wonderful. Deformations and reformations like these are doubtless one key to the popularity of Piers Plowman in the fourteenth and fifteenth centuries.

Langland's peculiar verse thinking occurred in a specific cultural setting. Departures from alliterative convention in Piers Plowman very often take the form of invitations to the syllabic meters that dominated fourteenth-century London literary culture. With that, I turn to the last case study and an even more aggressively avant-garde London poet.

\section{Multimetricality}

At the end of book 5 of Troilus and Criseyde, Chaucer apostrophizes the poem (quoted from Benson 1987):

And for ther is so gret diversite

In Englissh and in writyng of oure tonge, So prey I God that non myswrite the, Ne the mysmetre for defaute of tonge; And red wherso thow be, or elles songe, That thow be understonde, God I beseche!

("And because there is such great diversity in English and in the writing of our language, I pray to God that no one miswrite you, nor mismeter you due to an error of speech; and I beseech God that wherever you are read or sung, you be understood".)

(1793-1798)

This passage has attracted significant attention as a testament to linguistic, metrical, and textual variation in late medieval England (a characteristic critical engagement is Wogan-Browne et al. 1999: 11-12). The apostrophe appears to substantiate conclusions that medievalists are ready to accept anyway: that Chaucer's language, meter, and texts were in flux around him, and that Chaucer was exquisitely aware of this situation. In the standard interpretation, the speaker of the passage is a lot like a modern editor, worried about language change ("so gret diversite / In Englisshe"; "defaute of tonge"), metrical decay ("mysmetre", a nonce word), and scribal error ("writyng of oure 
tonge"; "myswrite"). Problems of transmission and interpretation pertain to both reading ("red") and performance ("songe"). Chaucer's voice speaks across the centuries, validating modern editorial solicitude.

I'd like to suggest a different cultural context for Chaucer's hand-wringing: the multifarious "metrical landscape" of late fourteenth-century London (Cole 2013). The previous two case studies focused on alliterative meter. With Chaucer, the focus shifts to the two other major fourteenth-century English meters, tetrameter and pentameter. Chaucer used the former extensively, and he invented the latter.

By historicizing early English metrical traditions, it becomes possible to attain some critical distance from the Troilus and Criseyde passage. Through apostrophe, Chaucer hints at the complexity of fourteenth-century vernacular poetics. Here, finally, modern scholars have caught a medieval poet thinking about English meter. However, Chaucer thinks about meter symptomatically rather than analytically. In Troilus 5.1793-1798, scansion crops up as a subset of a different activity: copying a manuscript. Scribal transmission, in turn, depends on language change ("for defaute of tonge"). The passage as a whole arises in response to a litany of authoritative classical poetry; in the previous stanza, the poet bids his "litel bok" (1786; 1789) go and "subgit be to alle poesye; / And kis the steppes where as thow seest pace / Virgile, Ovide, Omer, Lucan, and Stace" (1790-1792). This hierarchy of discourses - the classics, then the English language, then manuscript production, then prosody - has shielded from modern readers the specifically metrical meaning of Chaucer's anxieties. Attention to the shape and prehistory of Chaucer's metrical landscape helps illuminate what Chaucer meant by the neologism 'mismeter' but also how meter could appear to Chaucer as a poetic problem in the first place. The following discussion picks out some phonological evidence for crosspollination between the tetrameter and the pentameter before exploring how Chaucer thinks through these meters.

The English tetrameter was invented in the late twelfth or thirteenth century under influence from French and Latin octosyllabic verse. By the time Chaucer set out to write his first major work, the Book of the Duchess, in the late 1360 s or 1370 s, the tetrameter was the readiest alternative to the alliterative meter. The metrical phonology of tetrameter reflects its medium-length history. While conservative, thirteenth-century word forms appeared in fourteenth-century tetrameter, they coexisted with contemporary spoken forms: 
$\begin{array}{lllllllll} & S & x & S & x & S & x & x\end{array}$

Yif he had eyen hir to beholde

("If he had eyes to see her")

(Book of the Duchess 970)

$\begin{array}{lllllllll} & S & x & S & S & x & x & S & x\end{array}$

And to beholde the alderfayreste.

("And the fairest of all to behold")

In line 970 , the infinitive beholde counts an inflectional $-e$, assuming elision between eyen and hir. In line 1050, the $-e$ in beholde is discounted in scansion, assuming elision between the and alderfayreste as well as compound stress and stress shift in álderfayréste.

In the 1380s, Chaucer did something extraordinary: he invented a meter and inaugurated a metrical tradition that would go on to dominate the English literary field. Troilus and Criseyde is likely his first substantial work in this new verse form. ${ }^{5}$ In a pair of technical studies, Martin Duffell (2000 and 2014) shows in detail what Chaucer's pentameter owes to cosmopolitan metrical culture. According to Duffell, Chaucer was transposing to the English language habits of thought learned from consuming French and especially Italian meter. This research contributes metrical evidence to the ongoing reconsideration of Chaucer's cultural profile and the internationalization of English in the late fourteenth century (topics pursued by Butterfield 2009 among others). Belatedly, meter has joined literary style and social context as a criterion of Chaucer's European identity. Yet in categorizing Chaucer as a European poet who happened to write in English, metrists and critics deprioritize possible English literary backgrounds. When composing pentameter, Chaucer used a variable metrical phonology:

5 Other contenders are the Legend of Good Women and Parliament of Fowls (Lynch 2007). 
$\begin{array}{lllllllllll}x & S & x & S & x & S & x & S & x & S & x\end{array}$

Hym thoughte that his herte wolde breke

("He thought that his heart would break")

(Canterbury Tales 1.954)

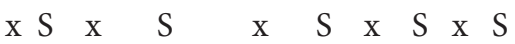

Into myn herte, that wol my bane be.

("[I was hurt through my eye] into my heart, which will be the death of me")

In line 954, herte ( $<\mathrm{OE}$ heorte) counts a historical $-e$, while in line 1097, the $-e$ in herte is discounted in scansion. If metrical phonology is an expression of metrical history, then a newly created meter ought to employ contemporary phonology. Where did Chaucer get those phantom e's? I suggest that the answer lies not in his wide reading in French, Italian, and Latin but in his prior metrical practice in English. Chaucer effectively translated the metrical phonology of the English tetrameter to the newer meter. In this way, the pentameter inherited some of the historical baggage of its key English precursor, the tetrameter.

Chaucer's phantom -e's are not often understood as a problem. Instead, they are mined as primary evidence for Chaucer's spoken language. The usual explanation for the variation evident in the metrical minimal pairs with beholde and herte is that Chaucer's London English had two different available forms, one conservative and one innovative. There exists a whole cottage industry in Chaucer studies built on epistemological feedback loops between meter and language. However, the reduction of metrical phonology to linguistic profile is precisely a refusal to see meter as a way of thinking different from other ways of thinking. Conflating metrical and linguistic forms $a$ priori, e. g., by discussing them together under a single rubric such as 'grammar', may obscure trace evidence of the phenomenological experience of verse craft. Certainly Chaucer engaged linguistic competence in versification; but he engaged much else besides.

Duffell's demonstration of Chaucer's French and Italian metrical influences stands; but I submit that Chaucer had English metrical influences, too. In particular, the tetrameter deserves more attention as a model for the pentameter. Chaucer, after all, devoted considerable energy to both meters. In one poem, 
he combines them. Anelida and Arcite is mostly composed in pentameters, organized into seven-line stanzas in rhyme royal $(a b a b b c c)$. The central section of the poem is "The compleynt of Anelida the quene upon fals Arcite", consisting of a proem, strophe, antistrophe, and conclusion. The "compleynt" is also mostly in pentameters, though organized into nine-line stanzas (aabaabbab). However, two sixteen-line stanzas, matched across the strophe and antistrophe, mix pentameters and tetrameters. The first half of the first of these multimetrical stanzas runs as follows:

Now, certis, swete, thogh that ye

Thus causeles the cause be

Of my dedly adversyte

Your manly resoun oghte hit to respite

To slen your frend, and namely me,

That never yet in no degre

Offended yow, as wisly $\mathrm{He}$

That al wot, out of wo my soule quyte!

("Now, truly, my sweet, although you, unjustly, are thus the cause of my grievous troubles, your noble reason ought to make you desist from killing your friend that is, me, who never yet offended you in any way, as surely as He who knows all redeems my soul from despair!")

$(256-263)$

Three tetrameters precede each line of pentameter. All six tetrameters rhyme together, and the two pentameters rhyme together, so that rhyme reinforces metrical identity. This poem is generally dismissed as a warm-up for the Knight's Tale. But Anelida and Arcite stages a starker confrontation between languages and meters than Chaucer was able to accomplish anywhere in the Canterbury Tales, even in the Tale of Sir Thopas. Over 250 lines into Anelida and Arcite, tetrameter intrudes on pentameter like a repressed memory. Like metrical symmetry in Gawain 2077-2078, or like the switch from seven-line stanzas to nine-line stanzas in this poem, the combination of tetrameter and pentameter cues a poem-within-a-poem - in this case, Anelida's "compleynt", which she writes down and sends to Arcite.

In making such a literary gesture, Chaucer was thinking through complex histories. The use of inset lyrics and the genre of the "compleynt" derive from medieval French literary culture. Chaucer's pentameter, however, has primarily Italian - and, as argued above, English - formal affiliations. The 
most prominent textual source for Anelida and Arcite is Boccaccio's Teseida. Finally, the Theban setting and the organization of the "compleynt" into symmetrical stanzas are classicizing details. A secondary source for the poem, announced by the narrator (1. 21), is Statius's Thebaid. Chaucer's career used to be conceptualized as a conversion from French to Italian influence; it is better conceptualized as a conversion from the tetrameter to the pentameter, a movement that cuts across linguistic categorizations. Anelida and Arcite epitomizes this shift in momentum within a poetic career. To embed Anelida's "compleynt" in the larger narrative, Chaucer had to be confident in putting forward pentameter as the unmarked mode and tetrameter as a form of hyperstylization. In doing so, Chaucer mobilized English, French, Italian, and Latin metrical histories in service of literary representation. Multimetricality appears as one of Anelida's coping mechanisms. Multimetricality might even contribute to "the balance between Christian contempt of the world and Boethian idealism about it" (Lynch 2007: 15) in Anelida and Arcite, though one would not wish to press an identification of meters with philosophies too far.

In light of the complicated and interconnected genealogies of Chaucer's two meters, the Troilus and Criseyde passage gains new significance. When Chaucer worries that readers will mismeter his poem, I think he is imagining scansion as a mental activity, not a copying error. Chaucer feared that readers would bring inappropriate expectations to the scansion of Troilus and Criseyde. This was an understandable concern in the 1380s, as Chaucer completed his first major poems in a new English meter. From the perspective of English metrical practice, the pentameter was initially a local meter; it would not escape the greater London area until the middle of the fifteenth century. Lacking a technical vocabulary for vernacular poetics, Chaucer conceptualizes unwelcome scansions as linguistic deficiencies ("defaute of tonge"). But modern scholars shouldn't accept this characterization at face value. The histories of the English tetrameter and pentameter provide a more robust context for the problem that Chaucer names. And the multimetrical play of Anelida and Arcite, whose dating is uncertain, implies that Chaucer was successful in inculcating a new metrical competence and avoiding metrical scandal.

As scholars have always recognized, Chaucer's ideas - about love, society, truth, God, etc. - come from many sources: Latin scripture, Boethius, French lyric poetry, Italian poetry, and other prestigious literary traditions. An old and rich vein of Chaucer scholarship addresses the poet's engagement with these sources of inspiration and authority. In this section, I've argued that tetrameter and especially pentameter ought to be numbered among the sources of Chaucer's ideas, and indeed that these meters provided a basis or pretext for all other ideas explored by Chaucer in verse. 


\section{Conclusion}

This essay has introduced three English meters - alliterative meter, tetrameter, pentameter - and explored some of the intellectual work performed within and between them in the late fourteenth century. Part of the essay's polemical purpose has been to recommend that more metrists understand themselves as intellectual historians, and that more historians of ideas understand themselves as metrists when they are considering ideas in verse form. What is ultimately at stake in these reorientations is the concept of thinking itself. If critics and historians tend to regard meter as a kind of ornamentation draped across pre-formed thoughts, metrists conversely tend to project literary thought as a series of manipulations posterior to an externally verifiable organizational system. For the critics, thinking comes first; for the metrists, meter does. In either case, meter and thinking are never allowed to coincide as they must in order for poetry to be produced and consumed in literary communities.

The particular coincidences of meter and thinking revealed above help historicize 'medieval literary theory' and, for that matter, literary theory in general. Early English meter as a way of thinking illustrates how subtle and flexible verse practice could be in the absence of explicit prosodic theory. Research on medieval literary theory may be excessively narrow in limiting investigation of medieval literary attitudes to explicit discussions of the vernacular. This essay has argued that the intellectual heft of a metrical tradition can be excavated from sedimented layers of verse practice and need not be sought in a collection of obiter dicta. In comparison with the richness of early English meter as a way of thinking, explicit discussions of the vernacular in medieval English texts must appear as rare, precocious, overdetermined intellectual engagements, whose scope normally does not extend to verse form for historical reasons. The practice of early English meter, considered as a kind of thinking, may be the closest thing to a vernacular ars poetica that medieval writers have bequeathed to modern scholars.

At the same time, it is important to reaffirm the distinction between thinking in meter and thinking about meter. None of the preceding discussion concerns 'theory' in the modern sense. The writings on English meter that began in the late sixteenth century with treatises by George Gascoigne and George Puttenham evince a qualitatively different disposition of mental energy. In the 1570s and 1580s, for the first time, vernacular meter became a suitable subject for academic discourse. Before that moment, attitudes toward meter can be inferred from poetic practice but are never expressed in concerted discussion. The nominalism shared by the New Criticism and the New Historicism has conditioned literary scholars to move from theory to practice, 
or from the term to the concept; the case of medieval English verse should tempt us to move (historically) from practice to theory, or from the concept to the term. In so doing, we might recover ways of thinking through poetry from which we have become historically estranged.

Finally, early English meter as a way of thinking helps contextualize a quintessentially postmodern problem. In recent decades, scholars, poets, and publishers have begun to worry that poetry is on the way out (Jackson 2008). This anxiety seems to me analogous to Chaucer's anxiety about mismetering, and equally misdirected. Certainly poetry has attracted new audiences and alienated others since the twentieth century; the same was true of poetry in the fourteenth century. But apprehensions about the transience of verse thinking probably underestimate the dynamism of poetic traditions. 'Poetry' is always a moving target, because metrical and intellectual histories are always under development. If we can learn to appreciate the radical experimentation of early English verse, then perhaps we can see our way past the twenty-first-century paradox in which poetry is both all-important and obsolescent. The future of poetry is by definition unimaginable: it has yet to be thought. ${ }^{6}$

6 Thanks are due to Arthur Bahr and participants in the MIT Ancient and Medieval Studies Colloquium for helpful discussion of a draft of this essay in March 2016, and to the two readers for Studia Metrica et Poetica for astute comments on a later version. 


\section{References}

Adams, Robert 1976. Langland and the Liturgy Revisited. In: Studies in Philology 73, 266-284.

Adams, Robert 2013. Langland and the Rokele Family: The Gentry Background to "Piers Plowman”. Dublin: Four Courts.

Alford, John A. 1977. The Role of the Quotations in Piers Plowman. In: Speculum 52, 80-99.

Alford, John A. 1992. "Piers Plowman": A Guide to the Quotations. Binghamton: State University of New York.

Andrew, Malcolm 1997. Theories of Authorship. In: Brewer, Derek; Gibson, Jonathan (eds.), A Companion to the “Gawain”-poet. Cambridge: D. S. Brewer, 23-33.

Andrew, Malcolm; Waldron, Ronald (eds.) 2010. The Poems of the Pearl Manuscript: Pearl, Cleanness, Patience, Sir Gawain and the Green Knight. $5^{\text {th }}$ ed. Exeter: Exeter University Press.

Barney, Stephen A. 2009. A Revised Edition of the C Text. In: Yearbook of Langland Studies 23, 265-288.

Benson, Larry D. (ed.) 1987. The Riverside Chaucer. Boston: Houghton Mifflin.

Burrow, John A. 2012. The Endings of Lines in 'Piers Plowman' B. In: Notes \& Queries 59, 316-320.

Butterfield, Ardis 2009. The Familiar Enemy: Chaucer, Nation, and Language in the Hundred Years' War. Oxford: Oxford University Press.

Cable, Thomas 1988. Middle English Meter and its Theoretical Implications. In: Yearbook of Langland Studies 2, 47-69.

Cable, Thomas 1991. The English Alliterative Tradition. Philadelphia: University of Pennsylvania Press.

Cable, Thomas 2009a. Foreign Influence, Native Continuation, and Metrical Typology in Alliterative Lyrics. In: Jefferson, Judith; Putter, Ad (eds.), Approaches to the Metres of Alliterative Verse. Leeds: Leeds Studies in English, 219-234.

Cable, Thomas 2009b. Progress in Middle English Alliterative Metrics. In: Yearbook of Langland Studies 23, 243-264.

Carlson, David 2004. Chaucer's Jobs. New York: Palgrave.

Cole, Kristin Lynn 2007. Rum, Ram, Ruf, and Rym: Middle English Alliterative Meters. Diss., University of Texas at Austin. 
Cole, Kristin Lynn 2013. Chaucer's Metrical Landscape. In: Carney, Clíodhna; McCormack, Frances (eds.), Chaucer's Poetry: Words, Authority and Ethics. Dublin: Four Courts, 92-106.

Cornelius, Ian 2012. The Alliterative Revival: Retrospect and Prospect. In: Yearbook of Langland Studies 26, 261-276.

Cornelius, Ian 2014. Langland's Latin B-verses. Paper read at the 49th International Congress on Medieval Studies, Kalamazoo, MI, May.

Cornelius, Ian 2017. Reconstructing Alliterative Verse: The Pursuit of a Medieval Meter. Cambridge: Cambridge University Press.

Duffell, Martin J. 2000. “The Craft so Long to Lerne": Chaucer's Invention of the Iambic Pentameter. In: Chaucer Review 34, 269-288.

Duffell, Martin J. 2014. Chaucer's Pentameter: Linguistics, Statistics, and History. In: Chaucer Review 49, 135-160.

Duggan, Hoyt N. 1997. Meter, Stanza, Vocabulary, Dialect. In: Brewer, Derek; Gibson, Jonathan (eds.), A Companion to the "Gawain"-poet. Cambridge: D. S. Brewer, 221-242.

Galloway, Andrew 2016. Imagining the Literary in Medieval English. In: Machan, Tim William (ed.), Imagining Medieval English: Language Structures and Theories, 500-1500. Cambridge: Cambridge University Press, 210-237.

Grady, Frank; Galloway, Andrew (eds.) 2013. Answerable Style: The Idea of the Literary in Medieval England. Columbus: Ohio State University Press.

Hanna, Ralph III 1993. William Langland. Aldershot: Ashgate.

Hanna, Ralph III 1995. Defining Middle English Alliterative Poetry. In: Tavormina, M. Teresa; Yeager, R. F. (eds.), The Endless Knot: Essays on Old and Middle English in Honor of Marie Borroff. Cambridge: D. S. Brewer, 43-64.

Jackson, Virginia 2008. Who Reads Poetry? In: PMLA 123, 181-187.

Jarvis, Simon 1998. Prosody as Cognition. In: Critical Quarterly 40, 3-15.

Jarvis, Simon 2014. What is Historical Poetics? In: Potts, Jason; Stout, Daniel (eds.), Theory Aside. Durham, NC: Duke University Press, 97-116.

Jefferson, Judith A. 2012. Scribal Responses to Latin in the Manuscripts of the B-Version of Piers Plowman. In: Jefferson, Judith; Putter, Ad (eds.), with the assistance of Amanda Hopkins, Multilingualism in Medieval Britain (c. 1066-1520): Sources and Analysis. Turnhout: Brepols, 195-210. 
Johnson, Eleanor 2013. Practicing Literary Theory in the Middle Ages: Ethics and the Mixed Form in Chaucer, Gower, Usk, and Hoccleve. Chicago: University of Chicago Press.

Johnston, Michael 2016. William Langland and John Ball. In: Yearbook of Langland Studies 30, 29-74.

Kane, George 1965. Piers Plowman: The Evidence for Authorship. London: Athlone.

Kane, George; Donaldson, E. Talbot (eds.) 1975. Piers Plowman: The B Version. London: Athlone.

Kennedy, Ruth (ed.) 2003. Three Alliterative Saints' Hymns: Late Middle English Stanzaic Poems. EETS OS 321.

Lawton, David A. 1980. Larger Patterns of Syntax in Middle English Unrhymed Alliterative Verse. In: Neophilologus 64, 604-618.

Lynch, Kathryn L. 2007. Dating Chaucer. In: Chaucer Review 42, 1-22.

Minnis, Alastair J. 2011. Medieval Theory of Authorship: Scholastic Literary Attitudes in the Later Middle Ages. $2^{\text {nd }}$ ed. Philadelphia: University of Pennsylvania Press.

Minnis, Alastair J.; Scott, A. Brian (eds.), with the assistance of David Wallace. 1992. Medieval Literary Theory and Criticism c. 1100-c. 1375: The Commentary Tradition. Rev ed. Oxford: Oxford University Press.

Pearsall, Derek 1977. Old English and Middle English Poetry. London: Routledge \& Kegan Paul.

Prins, Yopie 2008. Historical Poetics, Dysprosody, and The Science of English Verse. In: PMLA 123, 229-234.

Rosier, James L. 1964. “Instructions for Christians”: A Poem in Old English. In: Anglia $82,4-22$.

Russom, Geoffrey 2004. The Evolution of Middle English Alliterative Meter. In: Curzan, Anne; Emmons, Kimberly (eds.), Studies in the History of the English Language II: Unfolding Conversations. Berlin: Mouton de Gruyter, 279-304.

Somerset, Fiona; Watson, Nicholas (eds.) 2003. The Vulgar Tongue: Medieval and Postmedieval Vernacularity. University Park: Pennsylvania State University Press.

Steiner, Emily 2013. Reading "Piers Plowman". Cambridge: Cambridge University Press.

Stockwell, Robert; Minkova, Donka 1997. Old English Metrics and the Phonology of Resolution. In: Goblirsch, Kurt Gustav; Mayou, Martha Berryman; Taylor, Marvin (eds), Germanic Studies in Honor of Anatoly Liberman. Odense: Odense University Press, 389-406. 
Turville-Petre, Thorlac 1974. 'Summer Sunday', 'De Tribus Regibus Mortuis', and 'The Awntyrs off Arthure': Three Poems in the Thirteen-Line Stanza. In: Review of English Studies 25, 1-14.

Turville-Petre, Thorlac 1977. The Alliterative Revival. Cambridge: D. S. Brewer.

Turville-Petre, Thorlac 2003. Afterword: The Brutus Prologue to Sir Gawain and the Green Knight. In: Lavezzo, Kathy (ed.), Imagining a Medieval English Nation. Minneapolis: University of Minnesota Press, 340-346.

Weiskott, Eric 2013. Phantom Syllables in the English Alliterative Tradition. In: Modern Philology 110, 441-458.

Weiskott, Eric 2016. English Alliterative Verse: Poetic Tradition and Literary History. Cambridge: Cambridge University Press.

Wogan-Browne, Jocelyn; Fenster, Thelma; Russell, Delbert (eds.) 2016. Vernacular Literary Theory from the French of Medieval England: Texts and Translations, c.1120-c.1450. Cambridge: D. S. Brewer.

Wogan-Browne, Jocelyn; Watson, Nicholas; Taylor, Andrew; Evans, Ruth (eds.) 1999. The Idea of the Vernacular: An Anthology of Middle English Literary Theory, 12801520. University Park: Pennsylvania State University Press.

Yakovlev, Nicolay 2008. The Development of Alliterative Metre from Old to Middle English. Diss., University of Oxford. 